\title{
BEASTS FROM THE EAST
}

\section{FANTASIES OF EASTERN EUROPEANNESS IN BREXIT-ERA BBC DRAMA}

\author{
Júlia Havas \\ De Montfort University \\ julia.havas@dmu.ac.uk \\ Anna Mártonfi \\ Vrije Universiteit Amsterdam \\ a.martonfi@vu.nl \\ Gábor Gergely \\ University of Lincoln \\ ggergely@lincoln.ac.uk
}

\begin{abstract}
This article interrogates the figure of the Eastern European itinerant in contemporary prestige BBC drama to highlight the figure's role in mobilizing ideas of nationhood and foreignness in Brexit-era Britain. Our critical analyses of Dracula (BBC1, 2020), Killing Eve (BBC America, 2018-), and Call the Midwife (BBC1, 2012-) show that programming that putatively celebrates British multiculturalism and diversity configures the Eastern European foreigner as a threat to idea(I)s of Britishness, by deploying this figure in strikingly similar imaginaries of contagion, deviance, and savagery. Such treatment embeds these portrayals in discourses of white nationalism that seek to manage national belonging by articulating the limits and rules of the national community as implicitly racialized terms of culture and space.
\end{abstract}

Keywords: BBC drama, Eastern Europe, gender, Dracula, Call the Midwife, Killing Eve

\section{Introduction}

This article examines enduring racist-nationalist imaginings of the Eastern European other in British television fictions, demonstrated via Brexit-era ${ }^{1}$ BBC prestige dramas ${ }^{2}$ broadcast on UK television before international release via Netflix. We begin our discussion by briefly flagging up some of the key issues in the BBC1 miniseries The Salisbury Poisonings (2020), itself not our main object of study. This detour even before we begin our analysis proper is justified by the transparency of The Salisbury Poisonings' nationalistic rhetoric, which conjures up with no subtlety the toxicbeastly menace of Eastern Europe. We will then move on to three case studies, each focused on a drama series celebrated in critical and scholarly responses as progressive/joyous fictional representations of minoritized and/or marginalized bodies, ${ }^{3}$ to demonstrate the presence of the same imaginings of the Eastern European foreign other in our selected programmes, and to highlight how such dehumanizing representations can nestle within ostensibly 
empowering and positive discourses of identity. That is to say, the key claim we make is not that UK imaginings of the Eastern European other are newly xenophobic, nor do we pretend to draw attention to negative portrayals of Eastern Europeans in UK popular culture for the first time. Rather, we make the important point that ostensibly progressive fictional representations accommodate racist-xenophobic discourses of Eastern Europeanness, which remain unnoticed - or at least unremarked upon in celebratory critical responses - despite the obvious reproduction of age-old narratives of Eastern European savagery, barbarism and pathological threat in the Brexit era. The article is informed by a growing body of interdisciplinary scholarship on racialized European representations of Europe's margins, which it proposes to enrich with a theoretically and historically informed close reading of key examples of the BBC's internationally distributed prestige television drama output. ${ }^{4}$

The Salisbury Poisonings recounts the story of the 2018 attempt on the life of former Russian military officer and spy Sergei Skripal and his daughter Yulia, found poisoned with the nerve agent Novichok on a Salisbury bench. The attempted assassination, allegedly on orders of the Russian state, sparked an international diplomatic dispute, and also initiated a local public health crisis due to Novichok's extreme toxicity. In its efforts to characterise the poison's Russian victims as contaminating agents - foreign bodies that are a threat to a host body - and thus deny them the humanity or victimhood it attributes to the British casualties, The Salisbury Poisonings exhibits a startlingly direct xenophobia against the Eastern Europeans it sees as parasitic infiltrators. The narrative proper starts at the park bench where the two figures silently collapse. Their visual depictions are limited to distanced back-of-the-head long shots alternating with blurred faces in medium shots, the camera instead picking out passers-by in the background. Their features quite literally erased, the Skripals are denied agency or lines of dialogue throughout the series. The targets' attributed role is that of the foreign other bringing biopolitical danger home to the local community, which metonymically represents the national community.

The Salisbury Poisonings' celebration of British authorities and the local community authenticates itself through opening credits compiled of real BBC news footage, using the framework of a ripped-from-the-headlines realism. However, the montage of BBC news snippets kick-starting Episode 1 also makes clear that the lionization of collective national identity manifested in national-local and institutional-individual cooperation is predicated on xenophobic fearmongering against East European infiltrators of a coherent British national body. The opening credits' news montage effectively signals these concerns by reminding audiences of the cold spell that reached Southern England in March 2018. 'The Beast from the East,' as the weather phenomenon was christened by the tabloid press, is a descriptor repeatedly used in the title sequence, which strategically conflates this climate-change-induced extreme weather event with antidemocratic Russian politics by illustrating the headline and weather reports with images of Vladimir Putin ('Episode 1,' 1: 1). This evocation of Eastern savagery and invasion, a crude foreboding of the chilling threat from authoritarian Russia, heralds the series' approach to Eastern European presence in the UK, imagining the home nation both as landmass under threat and as the physical bodies of the (British) Novichok victims.

While The Salisbury Poisonings conveys its nationalist hostility against the Eastern European itinerant other directly, thanks to its generic positioning in the social-political BBC drama heritage that relies on topicality and social realism, ${ }^{5}$ our interest here lies more in excavating how this sentiment works in more opaque ways in genres not readily associated with social-issue storytelling. Thus, the analysis centres on three fictional 'genre' dramas: vampire horror Dracula (BBC1, 2020), period medical drama Call the Midwife (BBC1, 2012-), and crime thriller Killing Eve (BBC America, 2018-). These series, each of which imagines the Eastern European itinerant as a riddle to be solved, mobilize genres of fantasy and stylistic excess. Channelled through distinct genre vocabularies, in configuring the Eastern European foreigner as a threat to idea(I)s of Britishness, these series exhibit striking commonalities in using television genre tropes to conjure imageries of bodily contagion, geographic invasion, parasitism, backwardness, deviance, and savagery.

The drama programmes we discuss were produced with an eye for the global streaming marketplace as signalled by their international distribution by Netflix. These series are part of a cluster of programming that were commissioned by the BBC for international streaming and thus exporting ideas of Britishness, ${ }^{6}$ indicating that there are two dynamics at play with crucial implications for the racialized configuration of Eastern European-UK relations. First, while in the streaming era commentators place the BBC in a crisis narrative ${ }^{7}$ that sees Europe's oldest and most respected public 
service broadcaster in competition for digital territory with Netflix, the streaming giant carries a range of BBC programmes on its non-UK platforms under its 'Originals' banner. That is to say, Netflix plays a key role in promoting these programmes' configurations of Britishness as global cultural diversity overseas. ${ }^{8}$ So while BBC-produced prestige dramas speak to a British domestic audience of licence fee payers, offering up ideas of Britishness packaged within the public service remit of the broadcaster, they are also put to use as Netflix's own branded products, marketed and consumed as texts demonstrating the streaming giant's commitment to regionalism and transnational diversity. ${ }^{9}$ Thus the dramas examined sit in a sort of tension with themselves: they are both the articulation of a majority viewpoint, generously imagining an inclusive national space,${ }^{10}$ and examples of representation from a marginal position when viewed from the US-centred hegemonic position of Netflix. ${ }^{11}$ Second, and in part due to this dual positioning as centreyet-margin, the dramas in question belong to a range of contemporary Anglophone programming (produced for a global market) that aligns itself with the current surge of Western feminist and antiracist discourses by foregrounding 'diverse' female protagonists and authorship, tropes of the 'complex female character,' the female antiheroine ${ }^{12}$ and genderinverted leading roles, as well as themes associated with contemporary popular feminism ${ }^{13}$ such as women's bodily autonomy, resilience, multicultural female camaraderie, and queer desire. The BBC's declared commitment to representing diversity and a multicultural Britain ${ }^{14}$ aligns with these trends. Our article builds on existing scholarship on the broadcaster's construction of multicultural Britishness, in which the figure of the Eastern European itinerant is deployed as that which remains outside of an inclusive and diverse nation. ${ }^{15}$

Scholarship on crises of the BBC under broader economic, technological, institutional, and cultural shifts has engaged with how these shifts have affected the institution's original drama output in different eras. This attention points to drama's importance to the BBC's identity as producer of prestige programming and to the fulfilment of the corporation's public service broadcasting (PSB) remit. Given that the BBC is tasked with representing modern Britishness both domestically and transnationally, the desire to protect it from the consequences of the global streaming age is tantamount to a desire to protect national identity itself. Identifying the BBC with the national character is also undergirded by its drama outputs' recurrent efforts to position other state institutions as repositories of quintessential Britishness, such as the celebration of the National Health Service (NHS) in Call the Midwife, or the portrayal of the intelligence agencies in Spooks (BBC1, 2002-2011) and Killing Eve. ${ }^{16}$ Many of these dramas are carried transnationally, in turn, by the non-UK platforms of Netflix and Amazon Prime, which themselves trade in promoting global diversity and multiculturalism as part of their brand identities, couched in American understandings of progressive cultural politics. ${ }^{17}$ In a seemingly paradoxical synergy, which we argued above is the outcome of identical processes of seeking to project diversity, the series' cultural cachet of Britishness is channelled overseas through American streaming corporations, supposed threats to national PSB. Crucially to the argument we propose, the Britishness promoted hinges on BBC-legitimated antagonistic portrayals of Eastern Europeanness.

As indicated, the BBC's commitment to multiculturalism, gender equality and antiracism as part of its PSB remit has been criticised in scholarship for its contradictory implementation. For Malik, British television as a key site of modern Britain's self-representation "continues, in varying degrees and fashions, to resist these [values]." ${ }^{18}$ But following Ghassan Hage, we note that the BBC's purportedly progressive representational politics are not so much contradictory but are best understood as inherent features of white nationalist discourses in the modern nation state. ${ }^{19}$ For Hage, discourses of tolerance and intolerance, or racism and multiculturalism, are not dichotomous but sliding-scale expressions of an assumed right and power to manage the national space from a given rhetorical position. Since the choice to tolerate others presumes a pre-existing power to not tolerate,

...the difference between those who practise nationalist exclusion and those who practise nationalist inclusion is not one of people committed to exclusion versus people committed to inclusion, but rather one of people with different thresholds of tolerance. It is the discourse of the dominant that transforms this difference of threshold into a difference between tolerant and intolerant because in doing so it mystifies into an essentialist ethical choice (are you or are you not tolerant?) what is a socially determined differential capacity for tolerance. ${ }^{20}$

In relation to the BBC's purported embrace of multiculturalism and diversity, the issue is not simply how committed the corporation is to this policy. Rather, what is at stake is that such institutional discourses are part of the project of "realising the national will" to retain management rights of boundaries and limitations of inclusion and exclusion. ${ }^{21}$ 
In this case, the BBC's overt commitment to postcolonial, post-empire anti-racism helps gloss over the simultaneous projection of racist xenophobia onto the figure of the parasitic Eastern European. According to Rzepnikowska, who draws on Sivanandan, ${ }^{22}$ this is xeno-racism or cultural racism, a process in which nationalist exclusion becomes legitimized by categorising cultural-national difference as "not-quite-whiteness." 23 The notable increase in BBC drama configurations of the Eastern European as contagious, parasitic other, happens in tandem with its increased postempire, postcolonial tolerance discourse. In its shifting localization of the foreign racialized other, this exposes a continued underlying effort to exercise a national will by maintaining control in the cultural imaginary over who should and should not be tolerated.

\section{2 'The Rules of the Beast": The Dracula Miniseries as Immigration Fantasy}

It is an axiom in literary theory that Bram Stoker's Dracula expresses Victorian-era British anxieties about what Arata calls "reverse colonization," or the racialized threat that Eastern European invasion represents to the Empire in decline. ${ }^{24}$ The BBC miniseries turns key aspects of the novel's immigration fantasy as contagion/contamination of British blood, bodies, landmass, language, and culture into literalized and often verbalized plot points, resonating especially strongly with Brexit-era British discourses on immigration. The axiomatic nature of this issue for literary theory is also demonstrated in the growing scholarly interest in reading the novel from the perspective of the migrant other: rather than foreign threat, according to Viragh, Dracula symbolizes the stateless refugee's experience, denied his own culture, language, and agency in the host nation. ${ }^{25}$ And while the vampire has become increasingly a figure of sympathetic identification and "no longer terrifyingly parasitic" in $21^{\text {st }}$ century popular culture, ${ }^{26}$ the BBC miniseries recalls earlier renderings of the vampire as a beastly threat. Episode 1's title, 'The Rules of the Beast,' makes this nonhumanity explicit. While highlighting Dracula's linguistic-cultural parasitism, the series elides his cultural background, which the novel is both fascinated by and portrays as racially-linguistically chaotic. ${ }^{27}$ In its avoidance to signal the Count's cultural background, the series is also notably different from one of its primary intertextual references, Tod Browning's 1931 film version with Béla Lugosi. While a range of allusions are made to that film's classic lines and iconographies (e.g. "I never drink wine" is repeatedly uttered), a key (extra-)textual aspect is left behind: the blueprint gains much of its meaning around the Count's Eastern European foreignness by casting Transylvanian-born Hungarian Lugosi, whose star persona in Hollywood was rendered through his accented foreignness. But just like this version of Dracula is uninterested in engaging with the Count's cultural background, film and media scholarship, although fascinated by vampires, avoids recognizing filmed versions of Dracula as immigration/exile allegories. ${ }^{28}$

It is worth lingering briefly with the question of casting choices for their ramifications on the Eastern European's position in the British cultural imaginary. Apart from the hugely influential instance of Lugosi, Dracula has overwhelmingly been played by Anglophone actors in the story's most widely known, Anglo-American versions. Yet Lugosi's presence looms large. Many of these performances, among them Claes Bang's here, allude to Lugosi's interpretation of the role, and, via a mimicry of, and intertextual play with Lugosi's performance, channel his Hungarian accent into a performance of national foreignness. The interplay between the actors' and characters' nationality is crucial here. In all three series native speakers of Germanic languages play Eastern Europeans: Bang is Danish; Russian Villanelle is played by English Jodie Comer; the Danish Kim Bodnia is Russian spy Konstantin in Killing Eve; the Norwegian-Polish Nina Yndis is Hungarian au pair Magda in Call the Midwife. These casting choices display the character's, and through that, the actor's skills at accent mimicry. Dracula's case is genre-specific: his bloodsucking has the added supernatural benefit that he acquires the victim's language and native accent via their blood, and thus can appear in the guise of a cultured Western gentleman. This feature of the character as cultural appropriator through violent exsanguination is never so directly expressed in the novel or later adaptations. Consequently, when he imbibes Jonathan Harker's blood, this does not only affect Dracula's rejuvenation and Harker's physical decomposition, which for Arata signals the novel's anxieties about British deracination, ${ }^{29}$ but a literal theft of 'authentic' English language and cultured accent. Through this 
narratively stressed identification of blood with native culture (language) and homeland, the miniseries conjures up eugenic imaginaries, literalizing Nazism's 'Blut und Boden' (blood and soil) slogan. ${ }^{30}$ With his appropriation of language via blood, Dracula poses a threat to English culture. When, in the same episode, Dracula also dons Harker's facial skin to deceive Mina, this Hannibal Lecter-style masquerade further confirms the nature of the threat he represents: he is able to mimic not only the language but visage of a real Victorian English gentleman to conceal his true beastliness. This mimicry involves the necessary disintegration of the mimicked, and thus represents a vital threat to the host country.

While the Eastern European beast's parasitic appropriation of language extratextually allows for the non-native English-speaking Scandinavian actor's display of mimicking an upper-class English accent, in the Count's first appearance as aged vampire hiding in his castle, this display of accent skill is reduced to affecting the stereotype of a 'Slavic' English accent. Indeed, if the miniseries foregrounds the significance of language in the Dracula story (as specific skill and as heterogenous linguistic makeup of the Empire as shown below), it is strikingly generic in portraying the Count's linguistic background, rendered all the more contradictory through frequent allusions to Lugosi's (Hungarian-accented) performance. It is worth thinking through these concerns via Dolly Wells' two Van Helsings. She first displays a thick Germanic accent in her $19^{\text {th }}$ century iteration as Dutch detective-nun stationed in Budapest, then a 'native' English one as Agatha's contemporary British descendant Zoe. Actorly display of virtuoso accent skills plays a key role in the miniseries' rendering of extratextual multinationalism/-culturalism, but this traffic in colourful uses of English seems to extend only to Indo-Germanic linguistic exchange for the leads at the expense of attention to Eastern European specificity. ${ }^{31}$

The series' fascination with singling out the Eastern European as cultural parasite in linguistic terms becomes increasingly literal, and is perhaps most directly articulated in Episode 2 ('Blood Vessel,' 1: 2). The linguistic parasitism expressed here is also predicated on the character's sexual irresistibility. The episode takes place on the ship Demeter that carries Dracula and other passengers to England, as he kills them one by one. The multicultural and -national makeup of those aboard ship, comprising Russian, Romanian, and German crew members, and Indian, German, British and Afro-Caribbean passengers, allows for the foregrounding of both a variety of accented usages of English as mediator language and, contrastingly, Dracula's linguistic parasitism that exists outside of this familiar (read human) notion of lingua franca English in the Victorian era. In one sequence not familiar from previous iterations of the story, Dracula, in his efforts to seduce a bedazzled Bavarian Duchess, excuses himself during their English-language conversation to find and feed from a Bavarian deckhand, so he can acquire his language and dialect. Returning to the dinner table, he continues the conversation in a just-now-learned/imbibed German, which helps him make a stronger emotional impression on the Duchess through linguistic bonding.

In this episode, scenes on the Demeter are intercut with his conversing with Agatha in an imaginary space, which allows for immediate diegetic reflection on his actions. Their debate revolves around his drive to kill, which Agatha describes as animalistic ("pig," "like a fox in a hen coop"), Dracula as cultured: "like a connoisseur in a wine cellar. One chooses one's vintages with care." Dracula poses as a picky aristocrat but as not affected by class distinctions in his choice of victims/blood: "The reds and the whites, I enjoy both: the Duchess and the deckhand." To Agatha's retort: "But you're careful with your diet," he says "I have to be, otherwise I would have reached England with the social skills of a Russian sailor." Indeed, his choosiness revolves around national belonging rather than class: the Russian sailor's presumed lowly social skills are explicitly linked to his national identity and not his class status. Dracula's Western aspirationalism as snobbery is consistently expressed in his further kills, which he limits to Indo-Germanic (British, German) victims, while all other non-Western passengers and crew escape his fangs. In one notable exception, he bites into Adisa (Nathan Stewart-Jarrett), the token Black passenger, whose accent and name imply an AfroCaribbean background; he immediately spits his blood out and throws the body away with a disgusted growl.

While the novel-Dracula has also been read as anti-Semitic stereotype of the Jew who is allied with similarly stereotyped Gypsies and Slavs, ${ }^{32}$ this Dracula represents an Eastern European migrant who aspires toward inclusion into Western Europeanness by racism and xenophobia against both his fellow Eastern Europeans and representatives of a multicultural colonial Empire. His threat is then twofold: a racialized Eastern Europeanness and 
his own backward racist-xenophobic attitudes are unacceptable for a multicultural Britain that embraces citizens of the Commonwealth, and that only sees this latter form of racism as problematic, while expressing its own xenoracism in racist-Dracula. That this revolves around language-related racialized otherness is articulated in Episode 3 ('The Dark Compass,' 1: 3), which introduces Lucy Westenra (Lydia West) as the only 'race'-swapped of the original story's ensemble of characters. The casting of a Black English actor in this role has resonances with the novel: for Arata, the story's "racial anxieties are clearest" in Lucy's case, as "Dracula's kiss serves to deracinate" her by unleashing a "monstrous sexual appetite" that occurs via a blood exchange with the Eastern European racialized other, which can only be rectified by infusing her with proper Teutonic blood. ${ }^{33}$ The miniseries literalizes the novel's racial-sexual anxieties by the casting choice, which at the same time aligns with contemporary practices of 'colourblind' casting and discourses of British media's multiculturalism. ${ }^{34}$ But another crucial consequence of this is the significance it lends to language as a vehicle for culture and 'race', emerging in the comparison between Adisa's and Lucy's, the only two Black characters', different uses: Dracula has no qualms about drinking from Lucy, but emphatically rejects Adisa, the $19^{\text {th }}$-century Afro-Caribbean manservant. The colonial culture Adisa represents, signalled through accent, disgusts Dracula, unlike Lucy's hip, $21^{\text {st }}$ century London Englishness. This contemporary British depiction of Eastern European perception of race as a parasitic aspirationalism toward Westernness is predicated on understanding race as a position of power, rather than skin tone.

Let us return to the starting point of Dracula's tripartite journey: Transylvania and the convent in Budapest which Dracula invades, and where he first meets his nemesis Agatha Van Helsing. The convent signifies a transitory space on the westerly end of the barbaric Eastern Europe that Dracula's castle represents. Such a geographic setup is familiar from Western imaginaries of the post-communist region, which see nations like Romania as the "primitive East" ${ }^{\prime 3}$ and "one of the last authentic destinations of dark tourism," while "Budapest or Prague [are considered] shinier places that have more confidently erased their communist past." 36 The scene in which Dracula arrives at the convent gate in the shape of a wolf forges a link between the Eastern European migrant other's spatial-geographic position and the significance of that spatiality for his innate, supernatural barbarism and beastliness. In a lengthy sequence (Video 1) that is the episode's gory money shot, he assumes human form by crawling out of the skin of the wolf, covered in blood and naked in front of an audience of horrified nuns.

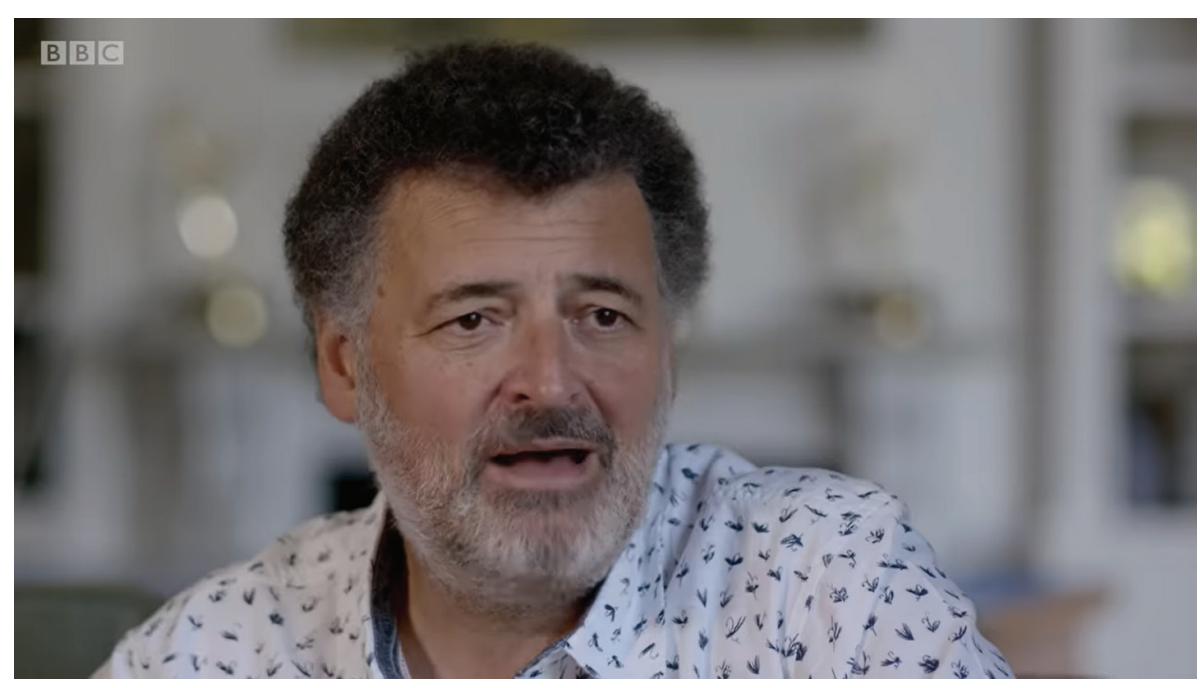

Video 1. The BBC's promotional behind-the-scenes video about the filming of the wolf sequence goes to great lengths to emphasize that this is the 'fantastically perverse' centrepiece of the episode.

Trapped outside the conduit space of Westernness, he reveals his true, viscerally abject bestiality, which also functions in gendered terms. But if the convent in Budapest is a bubble of safety, it is both a Western fantasy and a fragile stronghold. The miniseries' very first image shows the convent exterior situated on a hillside, accompanied by 
the legend 'Budapest 1897.' We never see more than this of 'Budapest,' and the impression is that of a small, remote village, not what it was in truth: a modernized capital city, recognized as an emerging European metropolis with all its associations of progress and vice. ${ }^{37}$ Yet the convent operates as an enclosed safe space of Westernness set apart from a rural remote elsewhere, involving a Western understanding of multiculturalism: it provides sanctuary for Harker and houses an ethnically diverse army of stake-wielding warrior nuns (close-up shots pick out Black and Asian women) trained by Agatha to fight the vampire. This confirmation of raced and ethnic diversity ignores geocultural and temporal specificity, projecting a Western-centric understanding of diversity onto a space that was ethnically, linguistically, culturally diverse in its own way, thereby erasing that specific diversity and, circuitously, aligning with a post-socialist erasure of past racial and sexual diversity. ${ }^{38}$

The other key motif of the episode, running through the miniseries as narrative enigma, is telegraphed in its title, 'The Rules of the Beast.' The title refers to Dracula's legendary weaknesses enumerated in a grandstanding speech by Agatha: his inability to cast a reflection (which denies his materiality ${ }^{39}$ ), and his aversion to sunlight and symbols of Christianity. The enlightened, scientistic Agatha's preoccupation with Dracula's unnatural existence revolves around seeking to understand why exactly these elements cause him harm. Different theories are offered and discarded, until in Episode 3, set in a scientifically enlightened 21 $1^{\text {st }}$-century England, Zoe/Agatha exposes Dracula's weaknesses as psychological, rather than supernatural barriers, confirming the triumph of Western logic and reason. In this regard, the convent is a transitory space in yet another aspect: as battleground between Agatha's rationalism and Dracula's atavistic, supernatural existence. Through this, the series also outlines a dyad between the two genre traditions which it seemingly hybridizes: the supernatural vampire fantasy and the English detective story. The latter is signalled through Agatha's first name, allusions to Sherlock Holmes, and Episode 2's whodunit plot. The two genres' dyadic signifiers (reason and humanism versus the supernatural and animalistic), focalized in the two attracted opponents, map themselves onto a dyad of enlightened, feminized Westernness and barbaric, masculine Easternness.

\section{Call the Midwife and the Question of Commonwealth versus Non-Commonwealth Immigrants}

This section turns to the BBC flagship programme Call the Midwife, a consistently popular Sunday night drama series $^{40}$ also known for its attempts at inclusivity in its plotlines. ${ }^{41}$ The storyline in our focus here concerns Magda, the Hungarian au pair who has a short-lived stint working as domestic help at the Turner household in series seven. She is glamourous, confident and full of sexual charisma - a far cry from the stereotype of the drab Hungarian émigré. ${ }^{42}$ By focusing both on the narrative and visual aspects of the programme, and particularly the episode arc involving Magda, this section outlines some of the deep-seated and problematic approaches to depicting Eastern European femininities, pinpointing the contrast between representations of Commonwealth and non-Commonwealth immigrants, and highlighting the difference between the perceived threat they are thought to pose to Britain. ${ }^{43}$

Just as in the case of Dracula, so too in Call the Midwife's Magda-storyline the question of accents and the casting of actors of Scandinavian origin have significance. As noted previously, Magda is played by the Norwegian-Polish Nina Yndis, who gives the nominally Hungarian character of Magda a 'Slavic' accent, which goes unchecked and unquestioned within the diegesis. As we argued with reference to Dracula, employing such a generic Eastern-European accent raises questions about homogenizing an entire region and about broader issues around racialized representation. The gesture, as we go on to show, denies specificity and coherence of self to the non-Commonwealth immigrant. This is thrown into sharp relief when viewed in parallel with a Commonwealth immigrant character introduced into Call the Midwife in the same season.

Magda's arrival coincides with the introduction of the much-awaited first Caribbean nurse to Call the Midwife's roster of characters: ${ }^{44}$ Nurse Lucille Anderson arrives to Nonnatus House in Episode 1 of series seven, while Magda turns up 
just one episode later. As the two characters' storylines run several parallels, they offer themselves for comparison in terms of narrative as well as aesthetic concerns. These include accents, acting, costume, colour palettes, as well as the notion of female-coded illnesses - a bladder infection in case of Nurse Anderson, and a pregnancy and illegal abortion for Magda, which leads her to resign and return to the Continent in disgrace. Perhaps most crucially, the two women travel inverse trajectories: Lucille's story takes her from suspicious-inauspicious beginnings to an unimpeachable moral position, whereas Magda's initial glamour and competence are put to the lie by her deceitfulness and moral laxity. The way the programme's aesthetics and narrative devices explore and depict these characters' trajectories inform discourses both around the conception of Commonwealth and non-Commonwealth immigrants and ideas about family values and motherhood within these contexts.

Evoking links not only to medical television but also to the British soap opera's ideological heritage around community and belonging, ${ }^{45}$ Nurse Anderson's introduction to the show is as an absence (she fails to arrive on time) and as a problem (she is ill, to boot). Although a negative start, it highlights the necessity of her arrival, and thus her anticipated utility to the community, disturbed by anxieties as to her suitability. The nurses and sisters of Nonnatus House soon find out her delay is caused by a spell of inclement weather. The same bad weather that delays Nurse Anderson and causes her illness, also puts the Turners' busy schedule under further strain and leads to their decision to engage the services of an au pair. The significance of this is, thus, twofold: within the narrative it is Nurse Anderson's delayed arrival that prompts Nurse and Dr Turner to reconsider their working and domestic situations and lead them to hire Magda in the following episode; while it is also during this delayed and difficult journey that Nurse Anderson contracts a debilitating bladder infection. The significance of the bladder infection lies in the type of illness it is, and in the way it is contextualized as a 'female' disease that affects the areas in/near the female reproductive organs. Nurse Anderson arrives significantly late, ill with an embarrassing, unsavoury, grim disease. Even the mise-en-scène of her arrival suggests that she is an infected element entering the healthy body of the NHS. In the very first scene she is onscreen, Nurse Anderson can be seen bundled up in a crimson woolly scarf as she makes her way towards Nonnatus House in a snowstorm at night. Thus hampered and weakened by her illness, she trips over in the muddy slush and injures herself. Seemingly, Nurse Anderson is a problematic element entering into the world of the Nonnatan nurses and sisters. However, her story arc in the first few episodes of season seven clearly demonstrates that despite this inauspicious first impression, Nurse Anderson proves her worth within the framework of the NHS, and thus within the broader framework of British society. Gesturing to her initial distance from the eventual host country, instead of a clean, efficient, punctual and implicitly implied - white nurse, a muddy, injured Black woman shows up late, without any of her luggage. The circumstances of her arrival, as well as her person, are in turn revealed as merely superficial and incidental. Her true worth and legitimate claim to belonging are demonstrated unequivocally: her illness is innocent (if unpleasant), and can be treated on the NHS, whereas Magda's pregnancy, and its termination, are intentional as well as morally and legally wrong.

While Nurse Anderson's Caribbean origins are emphasized in the programme, and there is extra-textual evidence highlighting the authenticity of the Caribbean accent produced by Leonie Elliot who plays her, ${ }^{46}$ there is less emphasis on Magda's origins, and - as mentioned above - no evidence either within the programme's framework or in extratextual materials of any aspiration to accuracy of representation in terms of accent performance. ${ }^{47}$ In the first episode of Magda's two-episode arc her origins do not come to the fore at all - rather, her previous au-pair position in Paris is mentioned, which also serves as a possible explanation for her glamourous appearance, and, perhaps, the pregnancy. The most prominent mention of her Hungarian origins takes place in a medical setting, when her examining physician exclaims that in the UK, unlike in Hungary, abortions are not legal. Her origins matter in terms of her morality, but not the specificity of her ethnic, linguistic, cultural, national identity. Her character, much like Dracula's, and as we will see Villanelle's, draws on a series of contradictions: where she is expected to be drab, ${ }^{48}$ she turns out to be glamorously Gallic (Video 2); but when focus turns to her sexual ethics, namely that she is unmarried, sexually active, and wants an abortion, her Hungarianness and distance from the legal-moral norm of Britain (and by extension the Commonwealth) takes on great significance. 


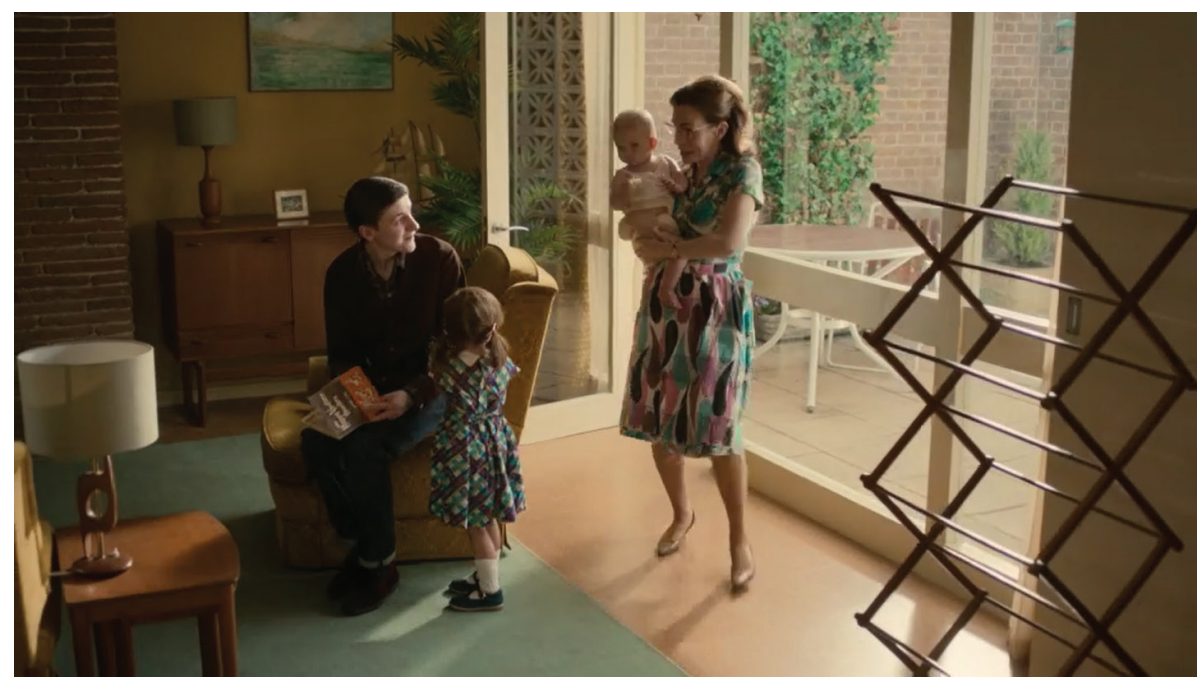

Video 2. For the glamourous Magda's introduction, see a promotional clip on the BBC One webpage.

As opposed to Nurse Anderson's suspicious-to-impeccable trajectory, Magda is introduced as an unexpectedly glamourous, beautiful, young woman who is efficient and friendly to boot, and whose fall from grace inversely reflects Nurse Anderson's rise. Whereas Magda is depicted as an immediately useful member of the Turner household clean, efficient, punctual and white - her utility is soon outweighed by the problems she presents. She is pregnant out of wedlock, and attempts a self-performed abortion. She does this by sneaking into Nonnatus House and injecting herself with an abortifacient. This misuse of NHS resources causes her to lose the Turners' trust and to expose her unacceptability as an immigrant in Britain. Her encounter with the NHS is nonetheless transformative. Her life, but not her foetus, is saved by the NHS, the same system she had tried to exploit and selfishly put under strain. Her disgrace is redemptive: she elects to return to the Continent to study nursing and voluntarily gives up her position, which had become untenable. Thus, a symbolic abortion happens: as a foreign body proven unfit, she ejects herself from the host nation, and in this roundabout way recovers the Turners' goodwill. Because Magda is an au-pair, an emphatically family-oriented position, her pregnancy, her desire to terminate it and misuse of a publicly funded system of national health, point towards her inability/unwillingness to adhere to and respect British family values. This notion has implications on two fronts: on the one hand, the fact that the Turners had not expected Magda to be either as glamourous or as efficient as she is signals ingrained stereotypical images of Eastern European women; on the other hand, this makes Magda's deception symbolic of the anxieties about Eastern European women worming their way not just onto British land but also into the sanctity of the British family.

Most scholarship on Call the Midwife and representations of racialized characters in BBC programmes agree that Commonwealth immigrants' representation can be ambiguous and controversial, ${ }^{49}$ but there is little mention of nonCommonwealth immigrants in these sources. When they are mentioned, they are contextualized as a unanimous threat: Burton draws the conclusion from analysing Call the Midwife, The Hour and The Bletchley Circle that "these shows together share an unquestioned presumption that immigrants who are not from the Commonwealth are a threat to the British way of life."50 Moreover, while Hamad draws a parallel between the arrival of Caribbean nurses into Britain in the post-war decades and EU citizens working as nurses in the NHS today, her assessment of the introduction of Nurse Anderson is oblivious to the problems of representation of Commonwealth and non-Commonwealth characters in Call the Midwife. By unpacking the parallel storylines of Nurse Anderson and Magda, it becomes clear that while Call the Midwife nods toward a 'progressive' representation in its characterization of Commonwealth immigrants, when it comes to non-Commonwealth immigrants, Burton's assessment holds true: Magda remains foreign, threatening and deceitful, and therefore needs to be expelled from the contexts of British domesticity. 
J. Havas, A. Mártonfi and G. Gergely, Beasts from the East

\section{The Eastern European Antiheroine in Killing Eve}

We now turn to Killing Eve to underscore how a series celebrated for its empowering representations of femininity and thus associated with a progressive project to centre complex female characters and their desires ${ }^{51}$ nonetheless makes use of the types of gendered and racialized anti-immigrant discourses we have identified in Dracula and Call the Midwife. Killing Eve's queerly fatal attraction between willful women Villanelle and the eponymous Eve Polastri has been understood as a powerful feminist narrative, ${ }^{52}$ feeding from showrunner Phoebe Waller-Bridge's authorial brand, based on Fleabag's (2016-2019) brutally and comically honest examination of feminine desire. ${ }^{53}$ While Villanelle's murders can be read as feminist liberatory assaults on embodiments of masculinist power (e.g. the Tuscan grand/ godfather, the British double agent who just wanted to provide for his family), this interpretation requires the reader's own wilfulness: ignoring Villanelle's coding as a chameleonic Eastern European working on the destabilization of Western capitalist liberal democracy. In other words, Villanelle may be a feminist killjoy who targets oppressive masculine authority, but she is also a foreign menace, a beast from the East. Indeed, this is made explicit when, in a scene that has its counterpart in both Dracula and Call the Midwife, the glamorous, beautiful and erotic Villanelle is made to confront her own real face, mediated by the putatively objective police camera and her Russian prison file with its mugshot of a sallow, brutalized, pitiable and abject Oksana. ${ }^{54}$

Just as the irresistible yet repellent Dracula, and the glamorous yet sordid Magda, Villanelle is riddled with contradictions: she is simultaneously outlandish in dress and behaviour and supremely able to infiltrate situations where she does not belong. She is desirable and desiring, but also sexless and limited in affective range. She is glamorous, but also plain, naïve and girlish (and sometimes boyish). She is assertive and aggressive, capable of great violence, but also disempowered and lacking agency. She is a feminist antiheroine, a complex female character, yet a cardboard cut-out caricature of thickly-accented Eastern European harshness and temper. Indeed, Villanelle is denied a coherent and stable identity. She is in fact a psychopath: a failing self that is a threat to other selves whose fears and desires she cannot comprehend and does not respect. In this sense she is no different than (or as different as) Dracula (Video 3 ).

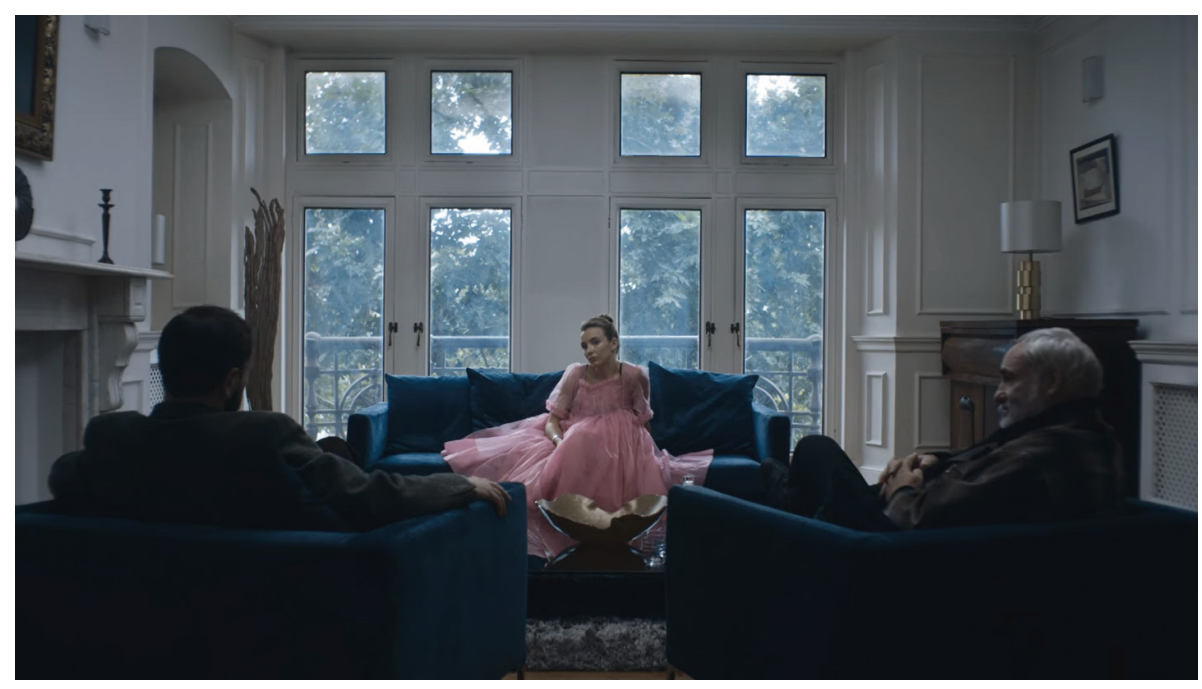

Video 3. In a BBC America teaser for the first series we see Villanelle assessed by her handler, Konstantin, and a psychiatrist, concerned that she may be losing the frame of mind necessary for dispassionate killing. She is wearing a much-discussed pink tulle dress and demonstrates psychopathic behaviours, both challenging and remaining wholly subordinate to masculine control.

This has consequences for what the character represents: while Villanelle's assaults on men and male-dominated institutions may stem from and serve the feminist project of undoing oppressive gendered power structures, the character, as imagined, is a product of xeno-racist and misogynistic visions of Eastern European femininity. 
The contradictory, irreconcilable character traits, and her psychopathic emotional disconnection from others bind Villanelle to post-enlargement discourses of Eastern Europeans as white yet racialized, unassimilable migrants who pose a threat to community cohesion in their country of settlement.

It is worth examining the series' arch opening scene ('Nice Face,' 1: 1), which playfully establishes Villanelle's skill at inveigling herself into spaces and relationships. Here we can see a technical coding of the series' concern with the uninvited crossing of borders and the resultant transformation of spaces of nurture and safety into sites of trauma. The scene, set in Vienna, a contact zone at the limits of Europe's West and East, serves the same function as Dracula's Budapest/convent scene: it reveals the beastliness of an initially attractive figure. Where Dracula relies on exposition and gore, Killing Eve encodes Villanelle's invasiveness into mise-en-scène. Let us therefore turn now to the series' first few shots. Power-dressed in black and white, accessorized with a blood-spattered Omega, Villanelle catches the eye of a little girl in an old-fashioned cake shop. Shots and reverse shots between Villanelle and the young girl are made unfamiliar as the camera reveals the waiter behind the counter engaging the girl's gaze with a beaming smile and a wink. What we first saw as shots of the girl looking at Villanelle are recoded as glances directed at the waiter. We see Villanelle's eyes and mouth in extreme close-up as she produces a replica of the waiter's smile. The girl adjusts her eyeline a fraction and smiles back at Villanelle now. Suddenly the waiter finds himself on the sidelines. Villanelle has displaced him and turned the girl's attention to herself. She has extracted from the girl a smile that grows from tentative to beaming. Satisfied with a relationship disrupted and a confidence gained, Villanelle leaves and as she walks past the girl, she flicks the ice cream bowl into her lap. We hear the commotion but cut to an exterior shot of the café as Villanelle smiles with satisfaction. This opening scene establishes Villanelle as a character with a total absence of empathy who delights in her skills to deceive and hurt. Her utter lack of any maternal instinct is fundamental to the character's credentials as a feminist antiheroine. However, this failure to align with gendered expectations is entangled with a mise-en-scène and performance of infiltration, uninvited penetration and disruption of an ordered and pleasant, if boring, norm. This shifts the emphasis from a powerful rejection of a powerless position to a troubling and hitherto unacknowledged embodiment of the same stereotypes of Eastern Europeanness that posit Magda as the superficially attractive but in truth morally and physically compromised and therefore dangerous foreign other.

It is important to underscore just how tethered both Villanelle and Eve are to masculinist standards and institutions, in spite of their ostensible defiance of male control and willful resistance to what Sara Ahmed calls the "straightening devices" of compulsory heterosexuality. ${ }^{55}$ This dependence on masculinist structures of power (Nurse Anderson and Magda's inverse trajectories writ large) is important, because it sets limits to what independence either one can achieve, while also highlighting key differences in the way Eve and Villanelle are gendered and racialized. Eve may be played by the U.S.-accented Asian-American star Sandra Oh, but she is rooted in a mundane world of British domesticity and office routine and is thus included in a position of unexceptional (British) normality presented as an ostensibly frictionless multiculturalism from which Villanelle is excluded ${ }^{56}$ Oh's off-screen position of power as executive producer - is replicated on the screen and can be apprehended in the character's familiarity and ordinariness, not to mention centrality to the narrative. Eve's job, arranging security for diplomatic visitors, that is to say limiting and policing what interactions overseas visitors may have on British territory, is crucial to the state's efforts to maintain its sovereignty. Her work is, therefore, fundamentally linked to policing a British national identity (this does not change when she is redeployed to the Villanelle taskforce). For U.K. audiences, in spite of her accent, Oh is a figure of identification. Indeed, to accommodate that accent, it is established early on that Eve was born in Britain and returned to live there after a childhood spent in the U.S. Through a combination of - colourblind ${ }^{57}$ - casting, characterization, performance and exposition, Eve is explicitly coded as an exemplar of the English-speaking audience, whether watching in the U.K. or the U.S.

By contrast, Villanelle's world is presented as universally alien. She moves with seemingly boundless freedom between scenes familiar from the frothy fantasy of big-budget tourism promotional films and racist imaginings of dour Eastern European wastelands. While in 'Nice Face' she deftly squeezes a tomato on a bruschetta astride a Moto Guzzi V7 in a sun-drenched Tuscan olive grove ${ }^{58}$ before killing a doting grandfather in his wife's Burberry maxi dress, ${ }^{59}$ in 'Take Me to the Hole' (1: 6) she is tricked into returning to a hellish women's prison in Russia, where she endures sadistic invasions 
of her privacy and violent bodily assaults, and is made to assume the costume and demeanour of victimized Oksana familiar from the prison file's mugshot. Tellingly, the mugshot is deployed once more in the third season in 'Are You from Pinner' (3: 5). This episode sees Villanelle return to Russia to meet her mother (Evgenia Dodina) and extended family. In a cavalier disregard for cultural and geographic specificity that we have highlighted across all series discussed here, the Russian village is played by a Transylvanian hamlet, Comandău in Romania, complete with a carved wooden gate characteristic of the region. Slavic-accented psychopathic murderer Villanelle is thus imagined as hailing from Dracula's neck of the woods. The show gives up all pretence of subtlety or complexity of characterization: Villanelle's family are painted with the broadest xeno-racist brushstrokes. They speak English with a thick accent, revere sauerkraut, fail to recognize Elton John's queerness, have a flair for bad fashion, are impassive yet impassioned, cynical in the face of death and have a closeness to nature expressed in the harvest festival, its dung-throwing competition, and the absence of infrastructure and technological development underscored by the fetishization of electronic gadgets. ${ }^{60}$ Much like Dracula is reduced to an object of knowledge over whom Agatha/Zoe Van Helsing claims total epistemic mastery, and Magda, too, is found out in more senses than one, Villanelle completes her journey from unknowable and seemingly uncontainable threat to a pitiable solved riddle, a sullen problem child. Indeed, the episode goes further than all others to present Villanelle as infantile in her passions, likes, hurts and actions.

Eve and Villanelle could not be more different. While Eve lives and works in the familiar terrains of the terraced house and the regimented and frustrating order of the office, but possesses governmental authority as a British state security official, Villanelle moves with ease between and across political, cultural, linguistic and emotional borders. Yet her freedom of movement is limited: she lacks what Hage calls managerial powers over the (national) community. ${ }^{61}$ The series systematically pits the two models of femininity against each other: each desires the other and thus desires otherwise, ${ }^{62}$ and each works on the other's destruction, that is to say, they desire outcomes that cannot both be achieved. And while other women characters play important parts, most notably Fiona Shaw as Carolyn and to a lesser extent Harriet Walter as Dasha, they do not represent different models of femininity. Rather, they echo and, through repetition, confirm Eve and Villanelle's respective positions as each other's opposite, as the one the other cannot but wants to have or be. Both are ostensibly empowered and empowering, but both are in truth constrained, defined in relation to their own position vis-à-vis the masculine, the paternal, and the ordinary. This entails a differential relationship to whiteness. Eve's Britishness is complicated - 'hyphenated', in Naficy's term ${ }^{63}$ - but uncontested, and her racialization is skin deep. By contrast Villanelle's aspiration to whiteness and accumulation of markers of a jetsetting Continental elite identity is routinely undercut by reminders of her originary Russian drabness, her paradoxical exoticism, and her psychopathic infantilism. These qualities remove her from the ordinary and root her in a xeno-racist vision of Eastern Europeanness that racializes her as not quite white.

\section{Conclusion}

This article has highlighted the centrality of discourses of the Eastern European itinerant's erotic/glamorous appeal undercut by contagious contact in Brexit-era BBC quality programming. It focused on television fictions rather than factual programming, to draw attention to enduring xeno-racist stereotypes in popular media representations outside of genres (e.g. reality television; news reportage) typically analysed in sociologically-oriented media scholarship for popular imaginings of the national community. ${ }^{64}$ However, as we have shown, the notion that the superficially healthy body of the foreign other hides contagion, that the erotic, seductive, sexually available queer body is a threat to healthy reproduction of the nation, a central plank of eugenistic discourses and scientistic racism which provided the basis for over a century of genocidal horrors, remains encoded in television fiction representations celebrated for their ostensible progressiveness in terms of their identity politics. ${ }^{65}$ In our theoretically and historically-grounded close textual analysis of Dracula, Call the Midwife's Magda storyline and Killing Eve, we have demonstrated that the Eastern European other remains conceptualized within a dehumanizing discourse of beastly threat, natural disaster, seductive toxicity and inclement weather; a discourse only intensified in Brexit-era Britain. We linked these xeno-racist patterns to long-established tropes of scientistic eugenic racism and made the key point that these are nestled within ostensibly 
progressive mainstream television programming of the present era, putatively produced to reflect a multicultural Britain to domestic and overseas audiences alike. Such programmes performatively imagine a British national identity characterized by frictionless ethnic diversity, while exploiting dehumanizing xeno-racist stereotypes of the itinerant Eastern European other in fictionalized representations of the United Kingdom's nostalgia-tinted pasts and Brexitinflected present. This demonstrates that the same assumed right and power to manage the national space is at work in the BBC's practice of inclusion that is claimed by those nationalists who, in Hage's analysis, yearn to produce and police a white nation. Our analysis of these series shows that the construction of a national space, whether aimed at a domestic audience addressed as the community that inhabits that space, or at an international audience positioned as a diverse and heterogeneous public inevitably entails the exclusion of bodies coded as failing to meet criteria for acceptance into the imagined community.

\section{Notes}

1. We use this term to mean the ongoing era of intense public debate around the UK's membership of the European Union triggered by David Cameron's 2015 Conservative election manifesto promise of an 'in-out' referendum.

2. Lez Cooke, British Television Drama: A History (London: BFI Publishing, 2015), 170.

3. Lucy Mangan, "Dracula review - a bloodsucking delight that leaves you thirsty for more," The Guardian, January 1, 2020, https://www.theguardian.com/tv-and-radio/2020/jan/01/dracula-review-bbc1-steven-moffat-mark-gatiss; Luce Brett, "Call the Midwife," Tortoise, April 9, 2021, https://www.tortoisemedia.com/2021/04/09/call-the-midwife/?utm_source=facebook\&utm_ medium=social\&utm_campaign=slow-reviews-call-the-midwife; Lynge Stegger Gemzoe, "Ironic Europe: Gender and National Stereotypes in Killing Eve," Akademisk Kvarter | Academic Quarter, no. 22 (2021): 137-148.

4. We draw on postcolonial scholarship such as: Manuela Boatcâ, "Thinking Europe Otherwise: Lessons from the Caribbean," Current Sociology 69, no. 3 (2020): 389-414; Merje Kuus, "Europe's Eastern Expansion and the Reinscription of Otherness in East-Central Europe," Progress in Human Geography 28, no. 4 (2004): 472-489. Our work sits alongside research on nonscripted television programming about Eastern European migrants such as: Anikó Imre, "How long can the party last? Gendering the European crisis on reality TV," in Gendering the Recession: Media and Culture in the Age of Austerity, eds. Diane Negra and Yvonne Tasker (Durham: Duke University Press, 2014), 246-272; Florentina Andreescu, "The Romanians are Coming (2015): Immigrant bodies through the British gaze," European Journal of Cultural Studies 22, no. 5-6 (2019): 885-907; and Vedrana Veličković, Eastern Europeans in Contemporary Literature and Culture: Imagining New Europe (Basingstoke: Palgrave Macmillan, 2019). We are also indebted to theorizations of Europe as centre, such as: Rosi Braidotti, The Posthuman (Cambridge: Polity, 2013) and Anikó Imre, "Postcolonial Media Studies in Postsocialist Europe," boundary 2 41, no. 1 (2014): 113-134. Moreover, our work builds on our own previous research, e.g. Gábor Gergely, Foreign Devils: Exile and Host Nation in Hollywood's Golden Age (New York: Peter Lang, 2012) and Gábor Gergely, "Sonority, Difference and the Schwarzenegger Star Body," Film Philosophy 23, no. 2 (2019): 137-158; Júlia Havas, "Socialist Superwomanhood and Policing the Nation in the Hungarian TV series Linda," MAl: Feminism and Popular Culture, no. 7 (2021), https://maifeminism. com/socialist-superwomanhood-policing-the-nation-in-linda/; Anna Mártonfi, "British Comedy in Foreign Light - looking at the trope of British comedy through the lens of émigré filmmakers," in Routledge Companion to European Cinema, eds. Gábor Gergely and Susan Hayward (London: Routledge, forthcoming).

5. Cooke, British Television Drama, 180-184.

6. Jeanette Steemers, "International Sales of U.K. Television Content: Change and Continuity in 'the Space in Between' Production and Consumption," Television and New Media 17, no. 8 (2016): 734-753.

7. See e.g. Peter Yorke, "Netflix Is Not the BBC," in The BBC at Nearly 100. Will It Survive?, ed. John Mair (Goring: Bite-Sized Books, 2021), 117-123.

8. Mareike Jenner calls this strategy "a grammar of transnationalism." See Mareike Jenner, Netflix and the Re-Invention of Television (Basingstoke: Palgrave Macmillan, 2018), 225-231.

9. Jenner, Netflix and the Re-Invention of Television, 175; Ramon Lobato, Netflix Nations: The Geography of Digital Distribution (New York: New York University Press, 2019), 69-71.

10. Ghassan Hage, White Nation: Fantasies of White Supremacy in a Multicultural Society (London: Routledge, 2000).

11. Jenner, Netflix and the Re-Invention of Television 175; Lobato, Netflix Nations, 145.

12. Milly Buonanno, ed., Television Anti-Heroines: Women Behaving Badly in Crime and Prison Drama (Bristol, UK and Chicago, IL: Intellect, 2017). For a critical interrogation of this type of celebratory scholarship see Júlia Havas, Woman Up: Invoking Feminism in Quality Television (Detroit: Wayne State University Press, 2022).

13. Sarah Banet-Weiser, Empowered: Popular Feminism and Popular Misogyny (Durham: Duke University Press, 2018). 
14. See e.g. section 6.4. of the BBC charter: http://downloads.bbc.co.uk/bbctrust/assets/files/pdf/about/how we govern/2016/ charter.pdf and the BBC website's Diversity and Inclusion page: https://www.bbc.co.uk/diversity/strategy-and-reports

15. Sarita Malik, Representing Black Britain: A History of Black and Asian Images on British Television (London: SAGE Publications, 2002); Glen Creeber, "'Hideously White': British Television, Glocalization, and National Identity," Television \& New Media 5, no. 1 (2004): 27-39.

16. Charlotte Brunsdon, "Bad Sex, Target Culture and the Anti-Terror State: New Contexts for the Twenty-First Century British Television Police Series," in Contemporary British Television Crime Drama: Cops on The Box, ed. Ruth McElroy (London: Routledge, 2016), 27-39; Cooke, British Television Drama, 223. Tributes to both the BBC and the NHS in the 2012 London Olympics' Opening Ceremony speak to these institutions' identification with exportable symbols of Britishness.

17. Jenner, Netflix and the Re-Invention of Television, 171-176; Michael N Goddard and Christopher Hogg, "Streaming Intersectionality: Queer and Trans Television Aesthetics in Post-Medium Transformation," Critical Studies in Television: The International Journal of Television Studies 14, no. 4 (2019): 429-434.

18. Malik, Representing Black Britain, 2.

19. Hage, White Nation.

20. Ibid., 92.

21. Ibid.

22. Alina Rzepnikowska, "Racism and Xenophobia Experienced by Polish Migrants in the UK before and after Brexit Vote," Journal of Ethnic and Migration Studies 45, no. 1 (2019): 64.

23. Ibid., 5.

24. See e.g. Stephen Arata, "The Occidental Tourist: 'Dracula' and the Anxiety of Reverse Colonization," Victorian Studies 33, no. 4 (1990): 621-645; Christine Ferguson, "Nonstandard Language and the Cultural Stakes of Stoker's Dracula," Elh 71, no. 1 (2004): 229-249; Nancy Armstrong, "Feminism, Fiction, and the Utopian Promise of Dracula," Differences 16, no. 1 (2005): 1-23; Stoyan Tchaprazov, "The Slovaks and Gypsies of Bram Stoker's Dracula: Vampires in Human Flesh," English Literature in Transition 58, no. 4 (2015): 523-535; Attila Viragh, "Can the Vampire Speak?: Dracula as Discourse on Cultural Extinction," English Literature in Transition 56, no. 2 (2013): 231-245.

25. Viragh, "Can the Vampire Speak?"

26. Angela Tenga and Elizabeth Zimmerman, "Vampire Gentlemen and Zombie Beasts: A Rendering of True Monstrosity," Gothic Studies 15, no. 1 (2013): 76.

27. Arata, "The Occidental Tourist": 629

28. For some important exceptions see e.g. Gergely, Foreign Devils; lain Robert Smith, "'For the Dead Travel Fast': The Transnational Afterlives of Dracula," in Transnational Film Remakes, eds. lain Robert Smith and Constantine Verevis (Edinburgh: Edinburgh University Press, 2017), 66-84.

29. Arata, "The Occidental Tourist": 631.

30. For the enduring impact of eugenics on postwar thought, see Dagmar Herzog, Unlearning Eugenics. Sexuality, Reproduction and Disability in Post-Nazi Europe (Madison: University of Wisconsin Press, 2018).

31. Viragh, "Can the Vampire Speak?": 240.

32. Jack Halberstam, “Technologies of Monstrosity: Bram Stoker's Dracula," Victorian Studies 36, no. 3 (1993): 333-352; Tchaprazov, "The Slovaks and Gypsies of Bram Stoker's Dracula."

33. Arata, "The Occidental Tourist": 632.

34. Christine Geraghty, "Casting for the Public Good: BAME Casting in British Film and Television in the 2010s," Adaptation 14, no. 2 (2020): 168-186; Kristen J. Warner, The Cultural Politics of Colorblind TV Casting (Abingdon: Routledge, 2018).

35. Alice Bardan and Anikó Imre, "Vampire Branding: Romania's Dark Destinations," in Branding Post-Communist Nations: Marketizing National Identities in the New Europe, ed. Nadia Kaneva (London: Taylor \& Francis, 2011), 169.

36. Ibid., 186. Exterior shots of Dracula's castle were filmed at Orava Castle which, although located in Northern Slovakia and as such not geographically close to the Transylvanian region, has symbolic linkage to this 'dark tourism': it was the filming location for F. W. Murnau's 1922 Dracula adaptation Nosferatu.

37. Anita Kurimay, Queer Budapest 1873-1961 (Chicago: University of Chicago Press, 2020), 1-18.

38. We point here to the decolonial and/or queer scholarship of Manuela Boatcâ, József Böröcz, Zoltán Ginelli, Anita Kurimay, Ervin Malakaj, and Sunnie Rucker-Chang among others.

39. Gergely, Foreign Devils, 97.

40. Hannah Hamad, “Take Four Girls'... And Diversify Them: The Evolving of Call the Midwife," CST Online, January 5, 2018, https://cstonline.net/take-four-girls-and-diversify-them-the-evolving-intersectionality-of-call-the-midwife-by-hannahhamad/

41. James Burton, "Reframing the 1950s: Race and representation in recent British television," in Adjusting the Contrast: British Television and Constructions of Race, eds. Darrell M. Newton and Sarita Malik (Manchester: Manchester University Press, 2017), 71-89; Hannah Hamad, "Contemporary medical television and crisis in the NHS," Critical Studies in Television 11, no. 2 (2016): 136-150.

42. Hamad, "Contemporary medical television and crisis in the NHS"; Hamad, "'Take Four Girls"; Burton, "Reframing the 1950s." 
43. Burton, "Reframing the 1950s," 85.

44. Hamad, "'Take Four Girls."

45. Hamad, "Contemporary medical television and crisis in the NHS": 136-137; Christine Geraghty, "Social issues and realist soaps: A study of British soaps in the 1980s/1990s," in To Be Continued: Soap Operas Around the World, ed. Robert C. Allen (London: Taylor \& Francis Group, 1995), 76-90.

46. Eleanor Bley Griffiths, "Who Is Leonie Elliott? Meet the Star Playing Call the Midwife's New Nurse Lucille Anderson," Radio Times (blog), n.d., https://www.radiotimes.com/news/tv/2018-05-11/who-is-call-the-midwife-new-cast-member-leonieelliott-nurse-lucille-anderson-series-7/

47. Gergely, Foreign Devils, 19.

48. Elza Ibroscheva, "Selling the Post-Communist Female Body," Feminist Media Studies 13, no. 3 (2012): 445.

49. Hamad, "Contemporary medical television and crisis in the NHS"; Hamad, "'Take Four Girls'”; Newton, "A little Brit different?"; Burton, "Reframing the 1950s"; Sarita Malik and Darrell M. Newton, "Introduction," in Adjusting the Contrast: British Television and Constructions of Race, eds. Darrell M. Newton and Sarita Malik (Manchester: Manchester University Press, 2017), 1-19.

50. Burton, "Reframing the 1950s," 85.

51. Buonanno, Television Anti-Heroines.

52. Chitra Ramaswamy, "From fridging to nagging husbands: How Killing Eve upturns sexist cliches," The Guardian, October 12, 2018, https://www.theguardian.com/tv-and-radio/2018/oct/12/from-fridging-to-nagging-husbands-how-killing-eveupturns-sexist-cliches; E. Deirdre Pribram, "Consorting with Criminality: The Female Detective in Killing Eve," MAI: Feminism and Popular Culture, 7 (2021), https://maifeminism.com/consorting-with-criminality-the-female-detective-in-killing-evel.

53. Havas, Woman Up; Júlia Havas and Maria Sulimma, "Through the Gaps of My Fingers: Genre, Femininity, and Cringe Aesthetics in Dramedy Television," Television \& New Media 21, no. 1 (2018): 75-94.

54. A popular Ukrainian name derived from the Greek for hospitality or stranger.

55. Sara Ahmed, Queer Phenomenology: Orientations, Objects, Others (Durham and London: Duke University Press, 2006$), 23$.

56. Pribram is notably oblivious to this dynamic. See Pribram, "Consorting with Criminality."

57. Geraghty, "Casting for the Public Good."

58. Exemplifying the tendency to attribute positive/progressive intent to Killing Eve's relentless stereotyping of non-UK settings, Gemzoe sees this as playful satire that riffs on travel films and the James Bond series. Gemzoe, "Ironic Europe: Gender and National Stereotypes in Killing Eve."

59. The dress was featured in a recent Elle rundown of Villanelle's finest looks: Olivia Barr, "Killing Eve: Villanelle's Best Ever Fashion Moments," Elle, June 8, 2020, https://www.elle.com/uk/fashion/celebrity-style/g32156498/villanelle-best-outfitskilling-eve/?slide=20.

60. Bardan and Imre, "Vampire Branding."

61. Hage, White Nation, 46.

62. Here we make reference to Ahmed's work on queer desire - see e.g. Sara Ahmed, Willful Subjects (Durham and London: Duke University Press, 2014).

63. Hamid Naficy, An Accented Cinema: Exilic and Diasporic Filmmaking (Princeton: Princeton University Press, 2001).

64. Andreescu, "The Romanians Are Coming (2015)"; Veličković, Eastern Europeans in Contemporary Literature and Culture.

65. See for instance Marius Turda and Paul Weindling, eds., Blood and Homeland: Eugenics and Racial Nationalism in Central and Southeast Europe 1900-1940 (Budapest: Central European University Press, 2007).

\section{Biographies}

Júlia Havas is Lecturer in Media at De Montfort University. Her research focuses on Anglo-American television, the gender and race politics of popular media, streaming culture, Hungarian film and TV, and the transcultural travel of media. Her monograph Woman Up: Invoking Feminism in Quality Television is forthcoming with Wayne State UP in March 2022. She has published in the journals Television and New Media, MAl: Feminism and Popular Culture, and Animation Studies, and contributed chapters to the anthologies Hysterical! Women in American Comedy (Texas UP 2017), Binge-watching and Contemporary Television Research (Edinburgh UP 2021) and The Routledge Companion to European Cinemas (forthcoming).

Anna Mártonfi completed her PhD at the University of East Anglia, examining transnational aspects of Jewish humour in British and Hungarian films in the inter-war era, and currently works as Lecturer at Vrije Universiteit Amsterdam, and as Visiting Lecturer at Universiteit Leiden. Her research interests include British radio, television and film comedy, transnational humour, Hungarian comedies of the inter-war era, and Jewish comedy. She is a contributor to the edited 
collections And Now For Something Completely Different - Critical Approaches to Monty Python (Edinburgh University Press, 2020) and The Routledge Companion to European Cinemas (forthcoming).

Gábor Gergely is a senior lecturer in film studies at the University of Lincoln. He works on European cinemas, representations of foreignness in Hollywood cinema, and industry regulation, film funding and anti-Semitism and racial nationalism in Hungarian film. His publications include the monograph Hungarian Film 1929-1947 (Amsterdam UP, 2017). He is the editor, with Susan Hayward, of the forthcoming The Routledge Companion to European Cinemas. His next book is Schwarzenegger: Uses of the Foreign Film Star (Palgrave Macmillan, forthcoming 2022). 